\title{
Power Relation and Reason's Contestation: Understanding Hadith on Islamic Websites in Indonesia
}

\author{
Ahmad Tajuddin Arafat ${ }^{1}$, Mokh. Sya'roni ${ }^{2}$, Titik Rahmawati ${ }^{3}$ \\ Universitas Islam Negeri Walisongo Semarang, Indonesia ${ }^{1,2,3}$ \\ \{tajuddin.arafat@walisongo.ac.id ${ }^{1}$, mokhsyaroni@walisongo.ac.id ${ }^{2}$, \\ titik.rahmawati@walisongo.ac.id $\left.{ }^{3}\right\}$
}

\begin{abstract}
The main background in this study is the fact that cannot be denied that any communication or information will be effective if it fulfills the elements of "who says what which channel, media and what effects". That statement seems relevant to be reconsidered in understanding, sorting and selecting Islamic websites in Indonesia as a reference as well as consumption of Islamic reading and studies. This study is important for knowing about who is behind the narrative of information is as important as knowing what is being narrated and the impact that is obtained from it. This study also important to know the narrative context of a hadith that is being explained on those websites, so that it is not uprooted from the historicity of its narration. By using mediatization theory, it can be concluded that the reason of the understanding hadith in the Islamic web can be classified into three categories, textual-literal reason, textual-interpretive reason, and contextual-liberative reason.
\end{abstract}

Keywords: Power Relation; Reason's Contestation; Hadith; Islamic Websites

\section{Introduction}

Islamic media, including Islamic websites, can be part of the channel for religious movements to voice the breath of Islam based on their ideological views, including the socioreligious issues that arise in Indonesia. The text that is narrated in those media is also symmetrical with the Islamic ideological platform it carries about.[1, p. 404] The online Islamic media was deliberately chosen because its existence was designed as an Islamic news media and in many ways represented the image of modern Islam [2, p. 50]. This study is not limited to seeing how the media documents the reality of socio-religious problems, but rather an effort to see how the construction of information is built in it.

Choirul Mahfud in his article straightforwardly states that the typology of Islamic mass media in Indonesia can generally be categorized into two types: prophetic journalism and provocative journalism. The first type is prophetic journalism, which seeks to disseminate information and news using language that is more friendly, polite, peaceful, soothing and dialogic. In this context, the quality of content produced is more emphasized than the issue of Islamic ideology alone. The second type is provocative journalism, which can be understood from the use of language and presentation of news carried out by editors who tend to be 
normative, provocative, intimidating, and anti-dialogical. This type of media is the opposite of prophetic journalism. The characteristics of this media and the language used appear provocative and spread hostility and invite conflict.[3, pp. 4-5]

Apart from these two types, the emergence of Islamic websites today is part of a da'wah effort that utilizes existing modern communication media. The existence and contribution of Islamic websites in carrying Islamic missions is not singular. Therefore, it is fitting for a reader to be wise in understanding the different characteristics between each of these media. Intentional or unintentional stereotypes in the public mindset as it has been perceived as pointing to an ideological orientation in the practice of journalism in Islamic media. Thus, the various religious ideologies on which the orientation of Islamic website activities is based are part of the idealism of Islamic websites in an effort to present Islam properly. With such idealism, Islamic websites want to serve as a means of enlightenment and education for users and readers

Based on the existing explanation, it is important to do this study by considering two main things; (a) the importance of knowing who is behind the narrative of information is as important as knowing what is being narrated and the impact that is obtained from it, and (b) the importance of knowing the narrative context of a mentioned hadith with the aim that the narrative of the hadith is not uprooted from the historicity of its narration.

This study uses the mediatization theory. Mediatization is useful to see religious phenomena in contemporary media. In this context, the mediatization theory here becomes one of the interesting things to see the phenomena and socio-cultural practice in which their presences are inspired by hadīth in the past and become a practice in the present. Religious modernity practice is a meeting point between religious norms and social context.[4] In this context, the understanding and belief that come from the hadith that presented on media are poured in the modernity paradigm by using new media through the illustrations and suitability with the current context. In media studies, this concept can be used in reading the mind of author and his narrative in approaching the text. Later we will see how Islamic website and the man behind the scene producing the meaning on their websites and how far it can be identified. Through this concept, we will also find out how the meaning of the hadith is presented on their website by linking to a form of relationship and motive constructed by the various powers and interests behind the scenes.

\section{Discussions and Results}

\subsection{Contesting the Hadith as Religious Discourses on Media}

Ibn Sirin $(\mathrm{d} .110 \mathrm{H})$ stated that the hadits or prophet's traditions are religious text, so see and observe who you take it from. The same thing was stated by Harold D. Laswell, that an information or communication is said to be effective if it fulfills the elements of "who says what which channel, media and what effects".[3, p. 3] Teun A. van Dijk on his Power and the News Media also said that media power is generally symbolic and persuasive, in the sense that the media primarily have the potential to control to some extent the minds of readers or viewers, but not directly their actions.[5, p. 10] Those statements seems relevant to be reconsidered in understanding, sorting and selecting Islamic websites in Indonesia as a reference as well as consumption of Islamic reading and studies.

Furthermore, information and communication technology is a new world situation known as community information in a global village. Technology as a social force is faced with the 
problem of who uses it and what interests are in it. Most of people well aware that technology and its mastery are not just an instrumental discovery that makes it easier for humans to access their lives, but there are problems in it related to power and politics or commonly known as a source of authority. In this sense, information and communication technology can be a hard power and soft power instrument. This is because the issue of media content has an impact on people's behavior. In this case, the information produced by media is very likely to be directed in the wrong direction, for example by creating a negative stigma against certain groups or it can be used to direct people to the order of life that is expected to live together.

That statement emphasized that whoever controls the information, he will be in power. Those who are strong in the economy, for example, usually also have strong control over information. Class inequality in the digital world has also led to the politicization of information technology and its content. Thus, they easily succeed in determining who is responsible for what and who in the information sphere. Usually the dominant group that controls information and technology is also able to control power and opinion in society.

Various media nowadays provide opportunities for all parties to share information on religious themes, such as about the hadith of the Prophet. The advancement of digital technology is increasingly open to documenting various materials of religious discourse both literally and visually. The internet media has made it easy for everyone to access the hadiths from sites that specifically provide the Prophet's hadith content and applications that are deliberately made to make it easier for everyone to access the Prophet's hadiths.

Sonnaonline.com and islamweb.net are examples of Islamic websites where one of the main features is the hadith of the Prophet. In Indonesia, Dr. Luthfi Fathullah, director of the Center of Hadith Studies, also offers a variety of hadith studies on his website called pusatkajianhadis.com. These sites have many features that offer the Prophet's hadiths with various transmissions and meanings, including features for religious consultation and Islamic content for adults and children.

In this case, Alfatih Suryadilaga stated that the advancement of information technology gave rise to various new products of hadith studies in digital media. He has recorded several advances in hadith products in the digital sphere. The most concrete examples are books in pdf format which can be downloaded for free in www.omelketab.net/chm/fiqeh/sobolelsalam.zip; www.omelketab.net/chm/fiqeh/alawttar.zip; http:/islamic-council.org/programs/Hadith4.zip; www.omelketab.net/chm/hadith/bokhari.zip; or at http:/www.saaid.net/book. In addition, there is also certain software initiated by individuals and other hadith researchers, such as Maktabah Syamilah, Maktabah Alfiyah li as-Sunnah al-Nabawiyyah and etc. Likewise, he also summarized and cataloged several articles on hadith studies in the global era in the form of ejournals, software, applications of hadith books as well as various studies on the YouTube channel.[6]

Like a hot issue that never gone, the hadith of the Prophet in this digital era is increasingly in demand by Muslims. It seems this is a clue that interacting with the hadith and his meaning in various aspects of life today is become of one sight to justifie the quality of practical belief of muslims. It is SUKA-Press UIN Sunan Kalijaga proofed by the prevalence of Islamic themes that make hadith as the main subject in their assemblies, both online and offline. This unstoppable flow of information and technology also has a significant influence on the various perspectives of Muslims on hadith. Lots of viral hadith broadcast through online media have become cognitive knowledge and become a new awareness in religious practice.

Hadith broadcast today has followed the logic of media. One of the evidence is the phenomenon of the hadīth explanation on Islamic website, YouTube channel and other social media. The narration is commonly viewing flayer and also audio-visual in telling events based 
on hadīth text which is claimed as a religious symbol. It is chosen one subject related to the current issue in Muslim society. Beside to fulfill the requirements of references for da'wah, quoting the hadīth and Qur'an verses was also to justify for the phenomenon which appeared in society. This justification could strengthen the argument or hujjah toward the entire mad'u/da'wah object.

Therefore, understanding a hadith in religious discourse posted on Islamic websites is not only sufficient to capture the literal meaning of a hadith that is narrated, but also requires a good awareness of the readers in seeking and well knowing about what is the main purpose of narrating that hadith relating with the phenomenon that occurred. So, here is where the ability to read, understand and analyze various sources in digital literacy is needed. It stated that digital literacy is the ability to understand and use information in various formats from multiple sources presented on a computer. This concept of literacy goes beyond the ability to read and it always means the ability to read both meaning and understanding, because it is the basic action of cognition.

\subsection{Understanding the Hadith on Islamic Websites in Indonesia: Case Study of Hadith Tasyabbuh}

The term understanding the hadith in the hadith sciences is commonly known as figh alhadith or fahm al-hadith. Those two terms are part of matan criticism (naqd al-matan), and it also is part of hadith criticism (naqd al-hadis).[7, p. 67] Meanwhile, hadith critical analysis (naqd al-hadis) consists of two part, there are sanad analysis (external criticism) and matan analysis (internal criticism). On the other hand, Syuhudi Ismail distinguishes between the terms of fahm al-hadith or fiqh al-hadith and naqd al-hadith. Fahm al-hadis or fiqh al-hadith is no longer talking about the issue of authenticity and validity of hadith transmission, but focused on the issue of how to interact with the hadith using a variety of approaches both historical, anthropological, psychological and also sociological. As for the naqd al-hadith (hadith critical analysis), it must involve the study of sanad and matan of hadith even though it is followed by explanation and interpretation. Because basically naqd al-hadith is an attempt to distinguish the quality of hadith, between what is true (valid) and what are not (invalid).[8, pp. 4-5]

There are at least two types of understanding hadith. First, the textual type, this type emphasizes the understanding of the Prophet's hadith without paying attention to the historical process of the presence of a hadith. This type emphasizes the literal meaning of a hadith text and focuses only on the linguistic aspect. Arifuddin Ahmad defines textual interpretation as a technique to understand the contents of a prophet's hadith which is limited to interpreting the text without considering the form and scope of guidance, time, asbab al-wurûd, the objectives of hadith, and ignoring other arguments and perspectives.[9, p. 205]

The second type is the contextualist type. The pattern of understanding the hadith through this type is considering the origin of the hadith (asbab al-wurud) or the historical context behind the text. Yusuf Qardhawi stated that the Prophet's hadith is the second source of Islaic teachings. Therefore anyone who wants to understand it must use the right method in the frame of Islamic teachings that are comprehensive, balanced and facilitate understanding.[10, pp. 17-21] According to Qardhawi, understanding the Sunnah of the Prophet through his hadiths must avoid extreme interpretations. It means interpretation without any basis method and full of manipulation and assumption.[10, pp. 22-26] In addition, understanding the hadith is also required to understand the role of the Prophet when he deliver his hadis, whether as a Messenger of Allah, a state leader, a person and so on.[10, pp. 33-34] 
Thus, understanding the Prophet's traditions can be understood textually and some are more appropriate when understood contextually. Textual interpretation is carried out when the hadith being studied still demands an understanding in accordance with what is written in the hadith text. The contextual interpretation is carried out in interacting with the hadith if there is a qarinah (clue) which requires the hadith to be understood not as a literal text. A good way to understand a hadith is to pay attention to the specific causes behind a hadith or its relation to a reason or cause stated in the hadith or it can be understood through the events that accompany it. $^{42}$

Next, Zunly Nadia states that different understandings of hadith certainly occur in various Muslim communities in Indonesia. These different communities indirectly show different views and interpretations of religious teachings and this is quite clearly visible in daily religious practice. According to Zunly, one of the causes of this difference in religious practice is their different understanding of the Prophet's hadith. Although the majority of Muslims agree that hadith is the second source of Islamic teachings after al-Qu'an, but there is no common understanding of the source of these teachings.[11]

One of hadith material that often is spread through media and Islamic website is related to the subject of tasyabbuh (resembling the other). From the preliminary research, it is obtained that the issue of tasyabbuh (resembling) with other communities, for example with nonMuslims, has always been a phenomenal and controversial social issue in Indonesia, especially if it is associated with certain contexts and situations, such as Christmas celebrations, New Year celebrations, Chinese New Year celebrations, and other cultural traditions. Muslims will always see this phenomenon through a religious perspective. This means that Muslims always try to find normative references and religious arguments that can be used as guidance and argumentation for or those who claim for or against this phenomenon.

Regarding the issue of tasyabbuh (resembling), Muslims usually base their religious attitude on one of the hadiths of the Prophet Muhammad which reads "man tasyabbaha bi qaumin fa huwa minhum (whoever resembles himself to a people then he is part of them)". The hadith comes from Ibn Umar and is narrated by many hadith scholars such as Ahmad bin Hanbal, Abu Dawud, At-tirmidzi and others. And the quality of the authenticity of the hadith is quite good

There are several Islamic websites that publish articles related to this hadith on their website, such as muslim.or.id, rumaysho.com, almanhaj.or.id, nu.or.id, islami.co, dutaislam.com, and islamlib.com. These websites simply narrated the theme of tasyabbuh which is linked to the context of traditions and culture in Indonesian society, especially which are closely related to interactions with non-Muslim communities in Indonesia. However, the explanation and the results of the articles that was published are not the same. For example, what is displayed in rumaysho.com and muslim.or.id is different from what is narrated in nu.or.id and dutaislam.com.

Based on the brief descriptions above, at least it can be explained that the reason for understanding the hadith of the seven Islamic webs can be classified into three categories, namely: textual-literal, interpretive textual, and contextual-liberative. The textual-literalist that is a model of understanding which shows a descriptive narrative that still focusing on the literal the hadith text. For example, the tasyabbuh theme described by al-manhaj.or.id[12], [13] and muslim.or.id[14], [15] seems to always emphasize the existence of concrete and clear boundaries based on the literal meaning of al-Quran and Hadith. In addition, an efforts to provide an open view towards a variety of interactions especially in the social sphere with the non-Muslim community are very measured by a very strict tasyabbuh projection. This type of understanding usually wants a clear boundary, especially regarding relations with the non- 
Muslim community, and the theme of the prohibition of tasyabbuh can be an argument for this attitude.

Second, textual-interpretive which is a approach of understanding that departs from text analysis and then it understood by means of dialogue with other texts that have similar themes. This approach, at least, still uses several analytical methods in reading the hadith texts, such as the methods of al-jam'u (compromising) and at-tarjih (preferencing). This understanding model is very readable in articles written in rumaysho.com,[16] nu.or.id,[17] dutaislam.com,[18] and islami.co,[19], [20] although there are some differences of point of views between them. For example, rumaysho.com and nu.or.id, both in the context of providing descriptions related to the theme of tasyabbuh not only dwelling on the text but also seeing the context of the text in which it is present. On the other side, nu.or.id, islami.co and dutaislam.com, have a broader interpretation of the theme compared to rumaysho.com. This three Islamic websites give the reason why resembling the others (read. Non-Muslim) are prohibited. becouse the position and the context where the narration of this hadith is in a situation where Muslims and non-Muslims are not in a peaceful situation. Thus, the prominence of certain identities by others becomes a sensitive issue at that time and the loyalty of a particular community is also determined by a distinguishing their identity from others.

The third category is contextual-leiberative. It is said that because the reading method used by the authority or the author on this site, from the beginning of the description, does not focus on the literal meaning and contextualized of this hadith. This kind of category is clearly stated and narated by islamlib.com. He said:

Therefore, we need to differentiate tasyabbuh into several categories. For example, we can formulate a legal maxim of this theme that at-tasyabbuh fi alibadat mahdzur (resembling with others worship practices is forbidden). That's the first. Second, at-tasyabbuh fi al-mu 'amalat mauquf (resembling other people's social order is situational). It's means, if there are things and positive attitudes that are equated, it actually becomes mustahab (recommended to do). Meanwhile resembling the negative things from others may be justified in the qualification of makruh or muharram (forbidden)[21]

That passage shows that the author or media authority tries to invite the readers to out off the horizon of the prohibition of tasyabbuh, and focuses more on other religious texts, which encourages Muslims to be more competitive gently or compete fairly with others. More than that, the position of those Islamic website mentioned above in relation to the tasyabbuh discourse can be categorized at least into two school of understanding. Pertama, arus pemahaman yang menginginkan batas pelarangan tasyabbuh lebih luas (soal akidah, syariat, dan muamalah) daripada kebolehannya. First, the school that wants to maximasized the prohibition of tasyabbuh (resembling the others) in all aspects of Islamic belief dan its expression than its permissibility. Second, the school that wants to minimized the scope of the prohibition of tasyabbuh (resembling the others) in small aspect, it's means only in scope of faith and sharia, not in the public sphare (muamalah).

\section{Conclusion}

Whether intentionally or unwittingly, the islamic websites thus plays a crucial role in the reproduction of meaning of hadis text in society. It does so not by simply voicing the attitudes of the muslim views, but by defining the identity of others in such a way that it persuasively 
influences the public by injection the new image to others by adopting these elite authority of those websites in the first place.

The formation of religious discourse in cyberspace, as in the study of a hadith, is determined by the strength of personal identity in the real world. The personal identity of each editorial member and writer on the Islamic website can be seen from the educational background and ideology of each member of the Islamic site. From this it can be seen how a hadith discourse is displayed on their website. Thus, awareness of the presence of a motive designed by a source of authority from a religious discourse in an Islamic web is very important for every reader.

Next, it can be confirmed that the reason of the understanding hadith in the Islamic web can be classified into three categories, textual-literal reason, textual-interpretive reason, and contextual-liberative reason. First, the textual-literalist that is meant is a model of understanding that only shows a descriptive narrative pattern that is still struggling with the literal side of the hadith text. For example, the tasyabbuh theme described by al-manhaj.or.id and muslim.or.id. Second, textual-interpretative, which is a model of understanding that is still based on text analysis and is then understood by means of dialogue with other texts that have similar themes. This model still uses several methods in reading the hadith texts, such as the methods of al-jam'u (compromising) and at-tarjih (preferencing). This model can be seen in articles written in rumaysho.com, nu.or.id, dutaislam.com, and islami.co, although there are still some differences between them. Third, contextual-leiberative, which is the reading method used by the writer on this site, from the very beginning of the description, does not focus on the textual meaning of this hadith. This kind of liberal reading model is represented by the authors on islamlib.com

\section{Acknowledgements}

This article and the research behind it would not have been possible without the exceptional support of our supervisors and reviewers. Their enthusiasm, knowledge and exacting attention to detail have been an inspiration and kept our work on track to the final draft of this paper. I would also like to thank the head and the staff of LP2M UIN Walisongo Semarang for enabling me to join their International Conference on Islamic Thoughts and History to present my paper.

\section{References}

[1] A. Mundiri and M. Tohet, "Contestation of Religious Identity in the Cyber World: A Case Study of arrahmah.com and VOA Islam Dealing with Religious Others on Facebook," Walisongo J. Penelit. Sos. Keagamaan, vol. 26, no. 2, p. 391, Dec. 2018, doi: $10.21580 /$ ws.26.2.3244.

[2] Rusmulyadi, "Framing Media Islam Online atas Konflik Keagamaan di Indonesia," $J$. Komun. Islam, vol. 3, no. 1 SE-Articles, Jun. 2013, doi: 10.15642/jki.2013.3.1.\%p.

[3] C. Mahfud, "Ideologi Media Islam Indonesia dalam Agenda Dakwah: Antara Jurnalisme Profetik dan Jurnalisme Provokatif," J. Dakwah Media Komun. dan Dakwah, vol. 15, no. 1, pp. 1-18, 2014.

[4] D. I. A. Putra and A. F. Chandra, "ediatization of Islamic Doctrine in a New Era of Digital Indonesia: The Case of Hadīth on Dajjāl," J. Theol., vol. 30, no. 2, p. 177, Dec. 2019, doi: 10.21580/teo.2019.30.2.4327. 
[5] T. A. van Dijk, "Power and the News Media," in Political Communication in Action : States, Institutions, Movements, Audiences, Cresskill, NJ: Hampton Press, 1996.

[6] M. A. Suryadilaga, Metodologi Syarah Hadis Era Klasik Hingga Kontemporer, Potret Konstruksi Metodologi Syarah Hadis. Yogyakarta: SUKA-Press UIN Sunan Kalijaga, 2012.

[7] Suryadi, Metode Kontemporer Memahami Hadis Nabi. Yogyakarta: Sukses Offset, 2008.

[8] S. Ismail, Metodologi Penelitian Hadis. Jakarta: Bulan Bintang, 1992.

[9] A. Ahmad, Paradigma Baru Memahami Hadis Nabi: Refleksi Pemikiran Pembaruan Prof. Dr. Muhammad Syuhudi Ismail. Jakarta: Renaisans, 2005.

[10] Y. Qardhawi, Bagaimana Memahami Hadis Nabi. Bandung: Karisma, 1993.

[11] Z. N. Nadia, "Perilaku Keagamaan Komunitas Muslim (Pemahaman Hadis dalam NU dan Salafi Wahabi di Indonesia)," J. Living Hadis, vol. 2, no. 2, p. 141, Mar. 2018, doi: 10.14421/livinghadis.2017.1327.

[12] Almanhaj, "Batasan Tasyabbuh, Menyerupai Orang-Orang Kafir," almanhaj.or.id. https://almanhaj.or.id/706-batasan-tasyabbuh-menyerupai-orang-orang-kafir.html.

[13] Almanhaj, "Kewajiban Iltizam Dengan Islam Dan Haramnya Tasyabbuh Kepada Orang Kafir," almanhaj.or.id. https://almanhaj.or.id/3698-kewajiban-iltizam-denganislam-dan-haramnya-tasyabbuh-kepada-orang-kafir.html.

[14] Y. Purnama, "Perbuatan Yang Dilarang Karena Tasyabbuh, Tidak Memandang Niat," muslim.or.id. https://muslim.or.id/29205-perbuatan-yang-dilarang-karena-tasyabbuhtidak-memandang-niat.html.

[15] Y. Pratama, "Fatwa Ulama: Batasan Dalam Menyerupai Orang Kafir," muslim.or.id. https://muslim.or.id/22750-fatwa-ulama-batasan-dalam-menyerupai-orang-kafir.html.

[16] M. A. Tuasikal, "Mengikuti Gaya Orang Kafir (Tasyabbuh)," rumaysho.com. https://rumaysho.com/3076-mengikuti-gaya-orang-kafir-tasyabbuh.html.

[17] H. Ferdiansyah, "Benarkah Menyerupai Nonmuslim Haram?," nuonline, Dec. 30, 2016. https://islam.nu.or.id/post/read/74224/Benarkah-Menyerupai-Non-MuslimHaram.

[18] dutaislam.com, "No Title." http://www.dutaislam.com/search/label/editorial.

[19] A. Sahal, "Natal dan Hadist Tasyabbuh," islami.co, Dec. 24, 2016. https://islami.co/natal-dan-hadist-tasyabbuh/.

[20] M. M. Irsyadi, "Tahun Baru dan Hadis Larangan Menyerupai Suatu Kaum," islami.co, Dec. 28, 2017. https://islami.co/tahun-baru-dan-hadis-larangan-menyerupai-suatukaum/.

[21] N. Kahar, "Seputar Hadis Tasyabbuh,” http://islamlib.com/, Jan. 02, 2016. http://islamlib.com/kajian/seputar-hadis-tasyabbuh/. 